\title{
ASSESS THE KNOWLEDGE AND PRACTICE OF REPRODUCTIVE AGED TRIBAL WOMEN ON FAMILY WELFARE METHODS
}

\author{
SAHBANATHUL MISSIRIYA ${ }^{1}$, MOHANA PRIYA ${ }^{2}$, PAVITHRA G. ${ }^{2}$, PAVITHRAN G. ${ }^{2}$, PRIYANKA K. ${ }^{2}$, SANDHIYA R. ${ }^{2}$
}

\author{
Saveetha College of Nursing, Saveetha University, Chennai \\ Email: contschn002@gmail.com
}

Received: 26 Sep 2016 Revised and Accepted: 08 Nov 2016

\begin{abstract}
Objective: Family welfare program has met with only marginal success due to different levels of awareness and acceptance of methods of family planning in various socioeconomic groups. Unmet needs of family planning are more in tribal population of the country. With this background the study was done to assess the knowledge and practice of family welfare methods among tribal women and to associate the knowledge of family
\end{abstract} welfare methods with the selected demographic variables.

Methods: A community based descriptive cross-sectional study was done. Reproductive aged women of 15-45 y were selected by convenient sampling method in the tribal area of Jawadhu hills.

Results: Among 200 women, 188 (94\%) of them had inadequate knowledge, 12(6\%) had moderate and none of them had adequate knowledge and practice of family welfare methods. There was no significant association between the knowledge and practice of the family welfare methods and the selected demographic variables such as age, educational status and education of her husband, religion, occupation, income, number of living children as well as source of family welfare information.

Conclusion: Use of contraceptive methods among tribal population is influenced by various factors. Health care provider should find the unmet needs of the individual tribal women before motivating them to adopt any suitable family planning methods to reduce the maternal complications.

Keywords: Knowledge, Practice, Reproductive aged women, Tribal, Family Welfare Methods

(C) 2017 The Authors. Published by Innovare Academic Sciences Pvt Ltd. This is an open access article under the CC BY license (http://creativecommons.org/licenses/by/4. 0/) DOI: http://dx.doi.org/10.22159/ijpps.2017v9i1.15397

\section{INTRODUCTION}

The ruling Janata Government in 1977 developed a new population policy that was to be accepted not by compulsion but voluntarily regarding family welfare programme [1]. Family planning means that the practices that will help the individuals or couples to avoid unwanted births, bring about wanted births, regulate the intervals between pregnancies. Medical practitioners and public health workers in India have been reporting that most of the people do not utilize the family welfare methods effectively especially in rural as well as hilly regions [2].

Studying the various demographic, socio economic and factors affecting the unmet needs among tribal women will go a long way in understanding the low level of contraceptive practices and would help formulate strategies to meet them. India was the first country to launch a family planning programme in 1952 [3]. During the first $50 \mathrm{y}$ there have been many changes. The name of family planning programme was changed to family welfare programme and lastly to the present reproductive and child health. The changes were done to increase the acceptance of family planning methods [4].

Spacing is an essential factor in reproductive life to promote health and well-being of mother and child [5]. Spacing between two children should be minimum of 3years to deliver a healthy baby. An adequate spacing is to recuperate mothers from physiological and psychological stress from pregnancy, delivery, and strain of taking care of the child. When mother's health is disturbed, whole family's routine will be disturbed a lot, as she is important fig. in the family. In developing countries especially in India where deep rooted belief, customs and superstition regarding childbirth, health and the role of the mother are widely prevalent. And women with poor socioeconomic back ground are more vulnerable to the health risks associated with child bearing in quick succession. These factors further contribute to high rates of maternal morbidity and mortality. In this situation, family planning plays a crucial role in safeguarding the health of women [6].
There are 11 major hill stations in Tamilnadu in which, Jawadhu hills is situated $75 \mathrm{kms}$ from Tiruvannamalai. It is situated in the north western part of Tiruvannamalai and Jawadhu hills are at Vellore district and Tiruvannamalai district. Around 80,000 populations live Jawadhu hills. Out of this 98 percent are from tribal community and two percent from other caste. The hill is around 2315 to 3000 feet higher from sea level. The total number of villages is in Jawadhu hills were 64. Total population of the village is 51,999 . In that total male is 26,483 and total female is 25,516 . The mean age at marriage for boys is $15 \mathrm{y}$ and for the girls is $13 \mathrm{y}$. Around $70 \%$ tribal people are illiterates and their marriage is strictly from their tribal community. The children have to walk for around 5 kilo meters to reach the elementary school. Very few children are going to school beyond eighth standard. Female education is neglected. Around $80 \%$ of the tribal peoples are living below to poverty line. Agriculture is there major occupation. More than $70 \%$ of adult men and women have venereal diseases. Reproductive tract infection is one of the health problems for women. Herbs are playing major role in treating illness, poison, wound healing as well as for contraception [7].

The family welfare programme was started in the year 1977, that India achieved the family welfare programme [1]. It is aimed at achieving a higher end that is to improve the quality of life of the people. In spite of this about $50 \%$ eligible couples in India are still unprotected against contraception.

Family planning has always been the main emphasis in population policies adopted by the government of India. However, there is a need of more public awareness and public participation. People do not have knowledge, concepts and practice regarding family planning among tribal peoples in Tamilnadu and this is not published in any magazines. Hence the researcher felt the need of family planning among tribal women residing at Jawadhu hills. Considering the above mentioned facts the investigator felt that there is a need to assess the knowledge and practice of family welfare methods among tribal peoples. Hence the study was started 
with the objectives of assess the knowledge of family welfare methods among tribal women, determine the practice of family welfare methods among tribal women and associate the knowledge of family welfare methods with the selected demographic variables.

\section{MATERIALS AND METHODS}

\section{Research design}

In observational research, descriptive design with one group method was chosen to assess the knowledge and practice of reproductive aged women on family welfare method. The setting of this study was at Jawadhu hill that was near from Vellore district of Tamilnadu. The villages were namely Peenchamanthai, Ettipatti, puliyamarathur, chengadu and palampattu. The Institutional Human Ethical Clearance (IHEC) was obtained from Saveetha University before initiating the study. The population was the reproductive aged tribal women. After providing information with clear explanation, the informed consent is obtained from all the reproductive aged tribal women residing at hilly regions of in Jawadhu hills, were selected as the sample for this study.

\section{Sampling method}

The sample size for this study was 200. Convenient sampling technique was used for the study. The inclusion criteria were tribal women in the age group of 18 to $45 \mathrm{y}$ that means in reproductive age and Married and eligible couple women.

\section{Instrumentation}

The tool used in the study included demographic variables of age in year, educational status of tribal women, educational status of her husband, religion, occupation, family income, age at marriage, number of living children, sources of health information and structured interview questionnaire method to assess the knowledge and practice of family welfare methods among reproductive aged tribal women. The score interpretation for assessing knowledge was $<50 \%$-inadequate knowledge, 50\%-75\%-moderate knowledge and $>75 \%$-adequate knowledge; for assessing practice, $<50 \%$-poor practice, $50 \%-75 \%$-satisfactory practice and $>75 \%$-good practice. The purpose of the study was explained to the women samples and their consent was obtained. Data was collected using structured Interview method. The main study was conducted in July 2016. The descriptive and inferential statistics were used for data analysis.

\section{RESULTS}

The collected data was analyzed and tabulated for the purpose of interpreting the results.

\section{Demographic variables of tribal women}

The frequency and percentage distribution of socio demographic variables of tribal women was shown in table 1 . Out of 200 tribal women majority $106(53 \%)$ were in the age group of 31-40 y. Most of the women $170(85 \%)$ were not having formal and basic education. Tribal women's husband also 182(91\%) were non-literate. Considering their religion all were Hindus.

Most of the tribal women $160(80 \%)$ were coolie workers and very few of them were housewives. Majority of them 196(98\%) were earning less than Rs.3000 per month. This was showing that the people were living at their poverty line in tribal.

Regarding their age at marriage, almost $176(88 \%)$ women got married at their age of below $20 \mathrm{y}$. Among tribal women 96(48\%) were having three children and $60(30 \%)$ were having more than three children.

Table 1: Frequency and percentage distribution of demographic variables of reproductive aged tribal women (n=200)

\begin{tabular}{|c|c|c|c|c|}
\hline S. No. & Demographic variables & & $\mathbf{F}$ & $\%$ \\
\hline \multirow[t]{4}{*}{1.} & Age & $15-20$ & 8 & $04 \%$ \\
\hline & & $21-30$ & 36 & $18 \%$ \\
\hline & & $31-40$ & 106 & $53 \%$ \\
\hline & & $41-45$ & 50 & $25 \%$ \\
\hline \multirow[t]{4}{*}{2.} & Educational status of tribal women & Non literate & 170 & $85 \%$ \\
\hline & & Primary & 30 & $15 \%$ \\
\hline & & High school & 0 & $00 \%$ \\
\hline & & Higher secondary & 0 & $00 \%$ \\
\hline \multirow[t]{4}{*}{3.} & Educational status of her husband & Non literate & 182 & $91 \%$ \\
\hline & & Primary & 10 & $05 \%$ \\
\hline & & High school & 8 & $04 \%$ \\
\hline & & Higher secondary & 0 & $00 \%$ \\
\hline \multirow[t]{4}{*}{4.} & Religion & Hindu & 200 & $100 \%$ \\
\hline & & Christian & 00 & $00 \%$ \\
\hline & & Muslim & 00 & $00 \%$ \\
\hline & & Others & 00 & $00 \%$ \\
\hline \multirow[t]{4}{*}{5.} & Occupation & House wife & 24 & $12 \%$ \\
\hline & & Coolie & 160 & $80 \%$ \\
\hline & & Self employed & 16 & $08 \%$ \\
\hline & & Private employee & 0 & $00 \%$ \\
\hline \multirow[t]{4}{*}{6.} & Family Income In Rupees/Month & $<3000$ & 196 & $98 \%$ \\
\hline & & $3000-5000$ & 4 & $02 \%$ \\
\hline & & $5001-10,000$ & 0 & $00 \%$ \\
\hline & & More than 10,000 & 0 & $00 \%$ \\
\hline \multirow[t]{4}{*}{7.} & Age at marriage & $<20$ & 176 & $88 \%$ \\
\hline & & $20-25$ & 24 & $12 \%$ \\
\hline & & $26-30$ & 0 & $00 \%$ \\
\hline & & $>30$ & 0 & $00 \%$ \\
\hline \multirow[t]{4}{*}{8.} & Number of living children & One & 2 & $01 \%$ \\
\hline & & Two & 42 & $21 \%$ \\
\hline & & Three & 96 & $48 \%$ \\
\hline & & More than three & 60 & $30 \%$ \\
\hline
\end{tabular}

F-Frequency; \%-Percentage; $n=200$ 


\section{Knowledge level of family welfare methods}

The frequency and percentage distribution of knowledge level of family welfare methods of tribal women were shown in table 2 . Out of 200 women, very few women $(6 \%)$ had moderate knowledge regarding family welfare methods that too regarding traditional methods like herbs and permanent sterilization methods only.

They not even aware of remaining temporary methods like oral pills and intra uterine devices and condoms.

Table 2: Frequency distribution of level of the knowledge regarding the family welfare method

\begin{tabular}{|c|c|c|c|c|c|c|c|c|}
\hline \multirow[t]{3}{*}{$\begin{array}{l}\text { Knowledge regarding the family welfare } \\
\text { method }\end{array}$} & \multicolumn{2}{|c|}{$\begin{array}{l}\text { Inadequate } \\
\text { knowledge }\end{array}$} & \multicolumn{2}{|c|}{$\begin{array}{l}\text { Moderate } \\
\text { knowledge }\end{array}$} & \multicolumn{2}{|c|}{$\begin{array}{l}\text { Adequate } \\
\text { knowledge }\end{array}$} & \multirow[t]{2}{*}{ Mean } & \multirow[t]{2}{*}{ SD } \\
\hline & No. & $\%$ & No. & $\%$ & No. & $\%$ & & \\
\hline & 188 & $94 \%$ & 12 & $6 \%$ & 0 & 0 & 0.02 & 0.15 \\
\hline
\end{tabular}

SD-Standard Deviation; Mean-Average knowledge level of family welfare methods; $(n=200)$

\section{Practice of family welfare methods}

The frequency and percentage distribution of practice of family welfare methods of tribal women were shown in fig. 1.

Out of 200 women, very few women (6\%) had satisfactory level of practice regarding family welfare methods. In that few of the women were undergone permanent sterilization method and few were using herbs as a practice $[7,8]$.

Majority $(94 \%)$ of the women were having poor or unsatisfactory practice level regarding family welfare methods.

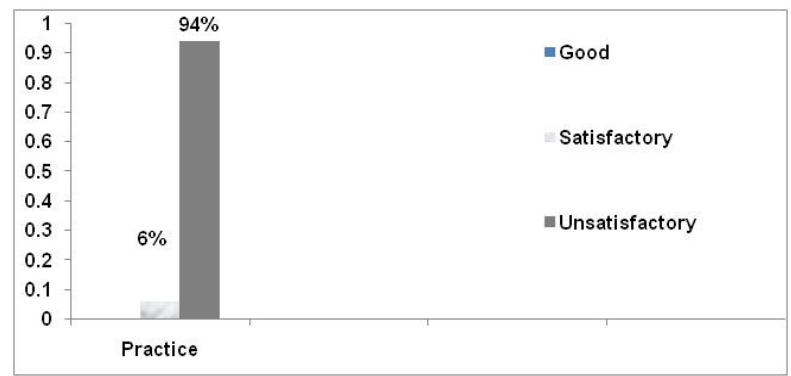

Fig. 1: Frequency distribution of level of the practice regarding the family welfare method

The women living at Jawadhu Hills were not having the acceptance of using any type of family welfare methods. They were ignorant about the importance of family welfare methods and the schemes of Government and benefits too.

The association between the knowledge of family welfare methods with the selected demographic variables showing that there was nonsignificant association between the knowledge regarding the family welfare methods and age, educational status, educational status of her husband, religion, occupation, income, number of living children, source of family welfare information among the demographic variables.

\section{DISCUSSION}

In this current study the distribution of knowledge on family welfare methods were showing that, none of the women were having adequate knowledge, $6 \%$ of women were having moderate knowledge and (94\%) were having inadequate knowledge. This was supported by the study on Family Planning Knowledge, Attitude and Practice among married couples in Jimma zone, Ethiopia was conducted by Tizta Tilahun, et al. (2013). In that study 854 married couples were participated and they were selected by multi-stage sampling design. Semi-structured questionnaire was used to collect the data. The analysis showed that the pills and injectable contraceptives were commonly known by both sexes, while longterm contraceptive methods were better known by women, and traditional methods as well as emergency contraception by men [9].

Another study was carried out by Sumana Basu, Anoop Kumar Kapoor and Salil Kumar Basu (2004) among two different tribal population groups namely Santal and Lodhas from West Bengal to determine their knowledge and attitude of family planning practice. Knowledge about contraceptive method was found to be universal among both Santaland Lodhas tribes. Because of low education level and unemployment the respondents did not give spontaneous response and they had poor attitude towards family welfare method [10].

The present study is showing the percentage distribution of practice on family welfare methods among tribal women, in that none of the women were not practicing any kind of temporary family welfare methods, only few $(6 \%)$ of women were undergone female sterilization methods.

Similar study was conducted by Donati Serena, et al. (2010), a survey on attitude on practice of family planning in Kakching, Manipur and reported that attitude of the female towards family planning methods was positive. But very few husbands (35\%) showed the positive attitude towards family planning. Among all $90 \%$ of females were in need of more information regarding family planning methods. And also $83 \%$ were in favour of sex education in school [11].

Chopra Seema and Dhaliwal Lakhbir (2009) had conducted a study on knowledge, attitude and practice of contraception in urban population of north India and reported that $55.2 \%$ study subjects were aware of contraceptive methods and majority of women had favorable attitude towards family planning. But considering the awareness of long-acting new methods was still not up to the expected level [12].

A study conducted by Rajesh Basnet et al. (2015) showed that people admitted in Tribhuvan University Teaching Hospital currently using temporary family planning methods were found to be $31.2 \%$. Among them 19 (24.7\%) were non-oral user and $4(6.5 \%)$ were oral users [13]

A study on knowledge, attitude and practice on Family Planning had done by Mao John (2007) at Tezu village of Manipur among 263 women which revealed a good knowledge and favorable attitude towards family planning. Tubectomy was more popular among most of women $(60 \%)$. Awareness to spacing method was only $20 \%$ which increased $76 \%$ after educating them [14].

There was no significant association between the knowledge regarding the family welfare methods and the selected demographic variables in the present study. But the study was conducted by Kisok Kim and Hyejin Priya (2016) on demographic factors associated with oral contraceptive use in Korean women. The resulted that the prevalence of oral contraceptive $(O C)$ use ranged from $14.8 \%$ to $16.0 \%$. Longer duration of OC use was positively associated with age and with increased cigarette smoking and decreased education. However, the use of OCs was not associated with body mass index, household income, alcohol drinking, or regular exercise [15].

\section{Limitation}

Few women felt shy to answer the questions during the data collection due to sensitive subjects.

\section{CONCLUSION}

The living standard of Jawadhu hill tribal people was poor. Health care facilities were also unavailable and not at their reachable. 
Majority of the people were having minimum three children or more than 3 children. And people were living at their poverty line and poor living standards. Hence, the family welfare among tribal group should be focused and there is a need to promote awareness about spacing and permanent methods in order to promote healthy life in India to reach millennium development goal.

\section{ACKNOWLEDGEMENT}

The authors are grateful to Dr. Mangala Gowri, Principal, Saveetha College of Nursing to permit and motivate to conduct study. Also authors are thankful to Mrs. Mahalakshmi and Mr. Dhinakar, Faculty, Saveetha College of Nursing to accompany throughout data collection period for their support.

\section{CONFLICTOF INTERESTS}

Declared none

\section{REFERENCES}

1. Kongawad P, Boodeppa GK. National family planning programme-During the five year plans of India. J Evol Med Dental Sci 2014;3:5172-8.

2. Bandhi G, Bhawnani D, Verma N, Soni PG. Assessment of contraceptive knowledge and practices among reproductive age group of women in urban slums of raipur city. Chhattisgarh, India, National J Community Med 2014;5:349-54.

3. Crichton J. Changing fortunes: analysis of fluctuating policy space for family planning in Kenya. Health Policy Plan 2008;23:339-50.

4. Singh RK, Devi T, Devi, Singh YM, Devi N, Singh N. Acceptability of contraceptive methods among urban eligible couples of Imphal, Manipur. Indian J Community Med 2004;29:13-7.

5. Abdel-Fattah M, Hifnawy T, Tarek I, Moharam MM, Mahmoud AM. Determinants of birth spacing among Saudi women. J Family Community Med 2007;14:103-11.

6. Da Vanzo JS, Habicht JP, Butz WP. Assessing socioeconomic correlates of birth weight in peninsular Malaysia: ethnic differences and changes over time. Soc Sci Med 1984;18:387-404.
7. Raj Kumar Keservani, Rajesh Kumar Kesharwani, Anil Kumar Sharma, Narendra Vyas, Anoop Chadokar. Nutritional supplements: an overview. Int J Curr Pharm Rev Res 2010;1:59-75.

8. Ariharan VN, Meena Devi VN, Parameswaran NK, Nagendra Prasad P. Physico chemical studies on soap nut [sapindus trifoliatus] oil for source as biodiesel. Asian J Pharm Clin Res 2015;8:88-90.

9. Tilahun T, Coene G, Luchters S, Kassahun W, Leye E, Temmerman $\mathrm{M}$, et al. Family planning knowledge, attitude and practice among married couples in Jimma Zone, Ethiopia. PLoS One 2013;8:e61335.

10. Basu S, Kapoor AK, Basu SK. Knowledge, attitude and practice of family planning among Tribals. J Family Welfare 2004;50:24-30.

11. Donati S, Nabakanta S, Medda E, Grandolfo M. Knowledge, attitude and practice survey on family planning in Kakching subdivision, Manipur state, India; 2010.

12. Chopra S, Dhaliwal L. Knowledge, attitude and practice of contraception in urban population of North India. Int J Gynecol Obstet 2010;281:273-7.

13. Rajesh Basnet, Neelam Pradhan, Laxman Bharati, Nirajan Bhattarai, Buddha Bahadur Basnet, Bidur Sharma. To determine the risk factors associated with ectopic pregnancy. Asian J Pharm Clin Res 2015;8:93-7.

14. Mao John. Knowledge, Attitude and practice of family planning, a study of tezu village, Manipur, India. Int J Biol Anthropol 2007;1:23.

15. Kisok Kim, Hyejin Priya. Demographic factors associated with oral contraceptive use in Korean women. Int J Pharm Pharm Sci 2016;8:299-301.

\section{How to cite this article}

- Sahbanathul Missiriya, Mohana Priya, Pavithra G, Pavithran G, Priyanka K, Sandhiya R. Assess the knowledge and practice of reproductive aged tribal women on family welfare methods. Int J Pharm Pharm Sci 2017;9(1):121-124. 